\title{
Synthesis, Characterization and Catalytic Activity of NiO-CoO-MgO Nano-Composite Catalyst
}

\author{
Salih Hadi Kadhim ${ }^{1, *}$, Tariq Hussein Mgheer $^{2}$, Hussein Idrees Ismael ${ }^{1}$, Khudheyer Jawad Kadem ${ }^{1}$, \\ Ahmed Saadon Abbas ${ }^{1}$, Abbas Jasim Atiyah ${ }^{1}$, and Iman Jassim Mohamad ${ }^{1}$ \\ ${ }^{1}$ Department of Chemistry, College of Science, University of Babylon, Hilla 51002, Iraq \\ ${ }^{2}$ College of Medicine, University of Babylon, Iraq
}

\section{*Corresponding author:}

email: hadi197019@yahoo.com

Received: August 15, 2018

Accepted: September 21, 2018

DOI: $10.22146 /$ ijc.38119

\begin{abstract}
The ternary NiO-CoO-MgO catalyst in three ratios 20:20:60, 25:25:50, and 30:30:40 for these component oxides respectively, were synthesized by co-precipitation method of their carbonates by addition of a precipitate agent in basic media and then calcinated these carbonate to obtain of mixed oxides. The prepared catalysts were characterized by using Powder X-Ray Diffraction (PXRD), Fourier Infrared spectroscopy (FT-IR), and Atomic Force Microscopy techniques (AFM). The result showed that the particle size of these catalyst ratios, were in the nano range and the smallest size was 25:25:50. The investigation of catalytic activity of prepared catalysts was done by photo decolorization of Celestine blue B dye from simulated industrial wastewaters in aqueous solution. The decolorization efficiency of dye reached $99.9 \%$ after irradiation time for 1 $h$. Study the effect of different reaction conditions such as the $\mathrm{pH}$ of the medium, the weight of semiconductor and temperature of mixture reaction were shown that the maximum degradation was observed in conditions at $\mathrm{pH}=4$, catalyst dosage $=0.08 \mathrm{~g}$, and temperature $=303 \mathrm{~K}$.
\end{abstract}

Keywords: decolorization of Celestine blue B dye; NiO-CoO-supported oxides; cobalt oxides

\section{- INTRODUCTION}

In the last few decades, catalytic processes have been emerged to be applied widely all over the world. This arises from industrial development which was accompanied by high levels of global warming as well as high levels of air, soil and water pollution. In this context, different catalytic materials were applied. Among different types of catalytic processes, heterogeneous catalysis processes play a significant role in the field of agriculture, pharmacy, and other industry manufacture because of their suitable design to give high selectivity and reactivity [1]. The purpose of preparation of the composite catalyst is to modified of the single catalyst properties such as activity, selectivity, thermal stability, and porosity, because of these properties are being very useful to give high reactivity in industrial chemical reactions. The composite catalyst also uses to reduce the environmental pollutants and to replace the classical fossil cells by the development of fuel cells and photovoltaic cells [2-5].

Among different forms of cobalt oxides, $\mathrm{CoO}$ is the most stable oxide for cobalt, and it has a wide range of applications such as environmental applications, electrochemical capacitors, hydrogenation processes, and in systems of energy storage. This oxide, consider as a very important type of a catalyst. It shows high photocatalytic activity for oxidation of the volatile organic compounds [6]. Nickel and cobalt oxides are used widely in photochemical reactions especially in the treatment of industrial wastewaters as well as others types of polluted water [7]. Generally, $\mathrm{NiO}$ has a distorted structure results from the arrangement of oxygen that gives holes between the neighboring ions of nickel [8]. Magnesium oxide is used as a catalyst and as a supporter of the active component of the catalyst 
support, and a modifier or promoter in heterogeneous catalysis [9-10]. On the other hand, $\mathrm{MgO}$ with a facecentered cubic lattice has many applications for catalysis reactions due to its strong surface basicity and high surface area. This enables $\mathrm{MgO}$ to be used in many basecatalyzed processes in a large number of organic reactions [11]. The composite materials led to altering the band gap and increasing the effectiveness of photocatalysts than the single oxide [12].

The present study describes the preparation of NiO$\mathrm{CoO}-\mathrm{MgO}$ in different ratios as a catalyst and studied the catalytic activity for decolorization of CBB dye from industrial wastewater and found the optimization as the best reaction conditions.

\section{- EXPERIMENTAL SECTION}

\section{Materials}

All chemicals that were used in the present work were of high purity. $\mathrm{Ni}\left(\mathrm{NO}_{3}\right)_{2} \cdot 6 \mathrm{H}_{2} \mathrm{O}, \mathrm{Co}\left(\mathrm{NO}_{3}\right)_{2} \cdot 6 \mathrm{H}_{2} \mathrm{O}$, $\mathrm{Mg}\left(\mathrm{NO}_{3}\right)_{2} \cdot 6 \mathrm{H}_{2} \mathrm{O}, \mathrm{HCl}$ and $\mathrm{NaOH}$ were purchased from BDH Company. Anhydrous $\mathrm{Na}_{2} \mathrm{CO}_{3}$ was obtained from Gmbh Company. Celestin blue b dye has the molecular formula of $\mathrm{C}_{17} \mathrm{H}_{18} \mathrm{ClN}_{3} \mathrm{O}_{4}$, the molar weight $363.80 \mathrm{~g} \mathrm{~mol}^{-1}$ and has a maximum absorbance at $644 \mathrm{~nm}$. This dye was supplied by Merck Company.

\section{Instrumentation}

The reaction cell has a quartz window and a volume capacity of $30 \mathrm{~mL}$. The UV radiation source in this cell was a mercury lamp which is supplied from Philips company-Holland $(250 \mathrm{~W})$. The $\mathrm{pH}$ of the mixture reaction was measured by a $\mathrm{pH}$ meter (type 740 Inolab WTW, Germany). The apparatus used was magnetic stirrer (Gallenkamp, England), Oven (BS Size 2 Gallenkamp, England) and Muffle Furnace (Size 2 Gallenkamp, England). Measuring of absorbance was conducted using a UV-Visible spectrophotometer (Shimadzu1100A, Japan).

\section{Procedure}

\section{Catalyst synthesis}

Mixed oxides, NiO-CoO-MgO was prepared with different ratios 20:20:60, 25:25:50, and 30:30:40\%, respectively from their primary materials. $\mathrm{Ni}\left(\mathrm{NO}_{3}\right)_{2} \cdot 6 \mathrm{H}_{2} \mathrm{O}$,
$\mathrm{Co}\left(\mathrm{NO}_{3}\right) \cdot 6 \mathrm{H}_{2} \mathrm{O}$, and $\mathrm{Mg}\left(\mathrm{NO}_{3}\right)_{2} \cdot 6 \mathrm{H}_{2} \mathrm{O}$. The equivalent amounts of mentioned ratios were accurately weighed and dissolved in $400 \mathrm{~mL}$ of distilled water. Adjustment $\mathrm{pH}$ of reaction mixture was kept equal to 9 by using a $\mathrm{pH}$ meter and this was achieved by the addition of a $\mathrm{Na}_{2} \mathrm{CO}_{3}$ solution $(1 \mathrm{M})$ to the reaction mixture with heating at $70-75^{\circ} \mathrm{C}$. The reaction mixture was kept at this range of heating temperature with continuous stirring for $2 \mathrm{~h}$. Then the mixture was filtered, washed and dried at 120 ${ }^{\circ} \mathrm{C}$ for $16 \mathrm{~h}$. The resultant solid was calcinated at $600{ }^{\circ} \mathrm{C}$ for $4 \mathrm{~h}$ with a heating rate of $10^{\circ} \mathrm{C} / \mathrm{min}$ [11].

\section{Characterization of the prepared nanocomposite catalyst}

X-rays diffraction technique (XRD). The ternary mixed oxides catalyst was investigated using powder Xrays diffraction (PXRD), type Siemens D500 with a $\mathrm{CuKa} \mathrm{X}$-ray source $\left(1.5418^{\circ} \mathrm{A}\right)$, with voltage $40 \mathrm{kV}$ and current $40 \mathrm{~mA}$. The scan range of $2 \theta=30-85^{\circ}$.

Fourier transform infrared spectroscopy (FTIR). The FTIR spectroscopy was used to identify the metaloxygen and surface bonds in the prepared co-catalysts using the FT-IR instrument which supplied from Perkin Elmer company-England in the range of wavenumbers from $400-4000 \mathrm{~cm}^{-1}$.

Atomic force microscopy (AFM). Surface morphology of the prepared co-catalysts was conducted with atomic force microscopy type SPM-AA3000, 2005, USA.

\section{The catalytic activity of the nanocomposite catalyst} The catalytic decolorization of Celestine blue B dye (CBB). The catalytic activity of the ternary prepared catalysts was investigated via following the decolorization efficiency of CBB dye. This was performed by adding $0.2 \mathrm{~g}$ from the used ratio of catalyst into $30 \mathrm{~mL}$ dye solution $(100 \mathrm{ppm})$. The reaction mixture was carried out at $25{ }^{\circ} \mathrm{C}$ with continuous stirring. The photocatalytic reaction was initiated by flushing UV radiation, and this was conducted after performing a dark reaction for each run and the period of dark reaction was $10 \mathrm{~min}$ for all performed reactions. Periodically, at every $10 \mathrm{~min}, 2 \mathrm{~mL}$ of the reaction mixture was withdrawn and centrifuged carefully many times. Then the absorbance of the obtained samples was 
recorded at $644 \mathrm{~nm}$ for $\mathrm{CBB}$ dye by using a UV-Visible spectrophotometer.

\section{Effect of catalyst doses on the decolorization of} CBB dye. The decolorization efficiency of CBB dye over the different weight of the prepared catalyst was studied by using $0.02,0.05,0.08$, and $0.1 \mathrm{~g}$ to choosing the best weight that which give a higher decolorization of the dye. A desired amount of the catalyst was added to $30 \mathrm{~mL}$ of dye solution of $100 \mathrm{ppm}$ and irradiate the mixture with UV-light at $298 \mathrm{~K}$ for $1 \mathrm{~h}$. For each experiment, withdraw $2 \mathrm{~mL}$ of the mixture after every $10 \mathrm{~min}$.

Effect of initial pH of decolorized of CBB dye over the prepared catalyst. The efficiency of dye decolorization was investigated in different $\mathrm{pH}$ of a mixture solution of $0.08 \mathrm{~g}$ of catalyst and $30 \mathrm{~mL}$ from 100 ppm of dye solution to choose the best $\mathrm{pH}$, that which give the maximum efficiency. The $\mathrm{pH}$ was adjusted by using $0.01 \mathrm{M}$ of sodium hydroxide and $1 \mathrm{M}$ of hydrochloric acid solutions. The reaction mixture was irradiated with UV light at $298 \mathrm{~K}$ for $60 \mathrm{~min}$. The decolorization efficiency was calculated by the equation: Decolorization Efficiency $\%=\left(A_{0}-A_{t} / A_{0}\right) \times 100$. Where the $A_{0}, A_{t}$ is the initial and the final absorption of dye, respectively.

Decolorization efficiency of CBB dye at different temperatures over Nano composite-catalyst. The effect of temperature of the reaction mixture on the efficiency of CBB dye decolorization over the used cocatalyst was conducted. A dye solution of $100 \mathrm{ppm}$, in 30 $\mathrm{mL}$ was suspended with the used amount of the cocatalyst, then the reaction was performed at different temperatures 288, 293, 298 and $303 \mathrm{~K}$ applying the same reaction conditions.

\section{- RESULTS AND DISCUSSION}

\section{Characterization of the Nanocomposite Catalysts}

\section{$X$-rays diffraction of the prepared catalysts}

Powder X-rays diffraction patterns of the prepared catalyst in their different ratios are shown in Fig. 1. These patterns refer to the appearance of the main diffraction lines of nickel, cobalt and magnesium oxides in the prepared catalyst. The result was confirmed from the comparison of these main diffraction angles $(2 \theta)$ and relative intensity $\left(\mathrm{I} / \mathrm{I}_{0}\right)$ of these main lines with the standard values of oxides, which mentioned and described in Joint Committee on Powder Diffraction Standards (JPDS) card no. 00-018-0408(N) JPDS card no. 00-003-0998(D). We can conclude and confirm the formation of the desired mixed oxides in the prepared catalyst [13] as in Table 1.

The crystal sizes of the prepared catalysts were calculated using the Debye-Scherer equation: $d=K \lambda / \beta_{1 / 2}$ ( $\cos \theta$ corresponding to the main diffraction lines of PXRD patterns of catalysts) [15], as shown in Table 2.

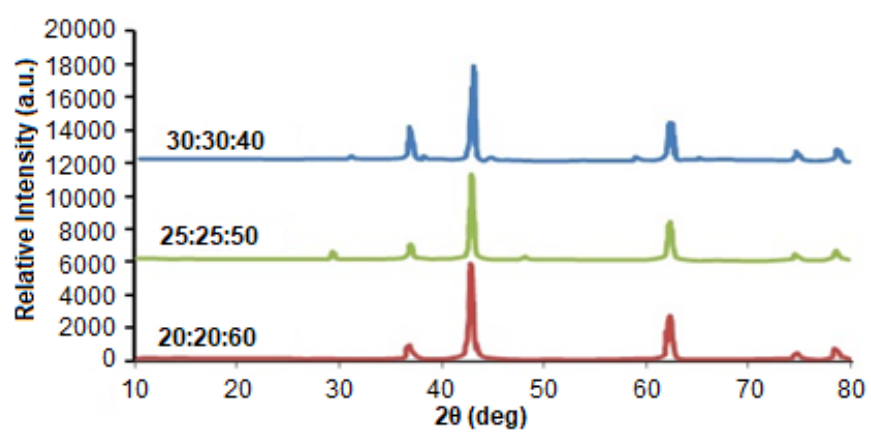

Fig 1. X-ray diffraction patterns of different ratios of ternary mixed oxides co-catalyst

Table 1. Diffraction angles $(2 \theta)$ and relative intensities $\left(\mathrm{I} / \mathrm{I}_{0}\right)$ of $\mathrm{CoO}, \mathrm{NiO}$, and $\mathrm{MgO}$ in Standard cards and prepared catalyst

\begin{tabular}{lllllllllllll}
\hline \multicolumn{4}{c}{ Standard Oxides } & \multicolumn{4}{c}{ CoO-NiO-MgO } \\
\hline $\mathrm{NiO}$ & & $\mathrm{CoO}$ & & $\mathrm{MgO}$ & \multicolumn{2}{c}{$20: 20: 60$} & $25: 25: 50$ & $30: 30: 40$ \\
\hline $2 \theta$ & $\mathrm{I} / \mathrm{I}_{0}$ & $2 \theta$ & $\mathrm{I}_{1} \mathrm{I}_{0}$ & $2 \theta$ & $\mathrm{I}^{\mathrm{I}} \mathrm{I}_{0}$ & $2 \theta$ & $\mathrm{I} / \mathrm{I}_{0}$ & $2 \theta$ & $\mathrm{I} / \mathrm{I}_{0}$ & $2 \theta$ & $\mathrm{I} / \mathrm{I}_{0}$ \\
\hline 37.2 & 60 & 36.9 & 10 & 37.1 & 10 & 36.7 & 13 & 36.8 & 22 & 37.0 & 39 \\
43.2 & 100 & 42.9 & 100 & 43.0 & 100 & 42.6 & 100 & 43.0 & 100 & 43.8 & 100 \\
62.9 & 35 & 62.4 & 39 & 62.2 & 75 & 62.3 & 42 & 62.4 & 62 & 62.9 & 47 \\
75.3 & 18 & 74.7 & 15 & 74.6 & 20 & 74.5 & 12 & 74.5 & 13 & 75.4 & 15 \\
\hline
\end{tabular}




\section{FTIR spectra for the prepared catalyst}

FTIR spectra of $\mathrm{NiO}-\mathrm{CoO}-\mathrm{MgO}$ in their different ratios are presented in Fig. 2, the appearance of frequencies bands in the position of 430-505 $\mathrm{cm}^{-1}$, which corresponds to Ni-O bond and $555-634 \mathrm{~cm}^{-1}$ due to vibration $\mathrm{Co}-\mathrm{O}$ bond. $\mathrm{Mg}-\mathrm{O}$ vibrational bands appear in the position of $680-875 \mathrm{~cm}^{-1}$, the shifting in these bands frequencies because of the differences in the percentages of the catalyst components, the stretching and bending vibration of $\mathrm{OH}$ group of the catalyst surface appears at $1400-1647$ and $3400-3450 \mathrm{~cm}^{-1}$, respectively [14-17].

\section{Atomic force microscopy (AFM) of the prepared catalyst}

The topographical nature of surface for the ratios: 20:20:60, 25:25:50 and 30:30:40 of CoO-NiO-MgO prepared catalyst, and particles size of these catalyst ratios and its distribution on the surface are shown in Fig. 3-5. From these results we can conclude that the best ratio of mixed oxides was $25 \mathrm{NiO}-25 \mathrm{CoO}-50 \mathrm{MgO}$, which exhibit a best topographical surfaces and smallest particle size $(72.55 \mathrm{~nm})$, while the other ratios $20 \mathrm{NiO}-20 \mathrm{CoO}-60 \mathrm{MgO}$ and $30 \mathrm{NiO}-30 \mathrm{CoO}-40 \mathrm{MgO}$ gives particles size equal to 86.52 and $97.92 \mathrm{~nm}$, respectively.

The average particle diameter that was calculated from the atomic force microscopy were in Nano range and show a good agreement with the data of crystal sizes

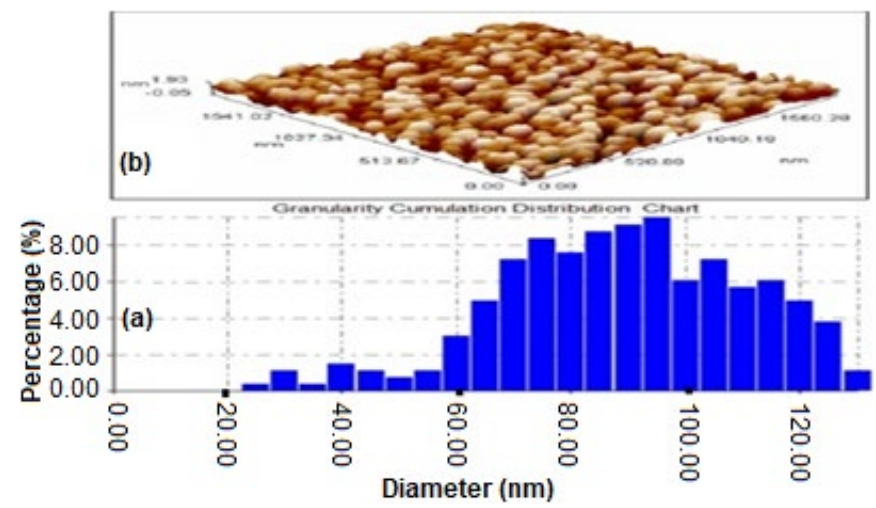

Fig 3. Atomic force microscopy for $20 \mathrm{NiO}-20 \mathrm{CoO}-$ $60 \mathrm{MgO}$ catalyst: (a) particle size distribution histogram, (b) image of surface of the prepared catalyst which is calculated from PXRD depending on Scherer equation.

\section{Band gap energy determination}

The band gap energies of the ratios: 20:20:60, 25:25:50, and 30:30:40 of the prepared catalyst CoO$\mathrm{NiO}-\mathrm{MgO}$, were investigated by using Plank's equation as shown in Fig. 6. This figure shows the band gap energies for the ratios of the prepared catalyst equal to $3.79,3.76,3.85 \mathrm{eV}$ respectively. The lowest value for the

Table 2. The crystal sizes of the prepared catalysts

\begin{tabular}{cc}
\hline Catalysts & Particle size $(\mathrm{nm})$ \\
\hline $20 \mathrm{CoO}-20 \mathrm{NiO}-60 \mathrm{MgO}$ & 19.43 \\
$25 \mathrm{CoO}-25 \mathrm{NiO}-50 \mathrm{MgO}$ & 16.61 \\
$30 \mathrm{CoO}-30 \mathrm{NiO}-40 \mathrm{MgO}$ & 27.36 \\
\hline
\end{tabular}

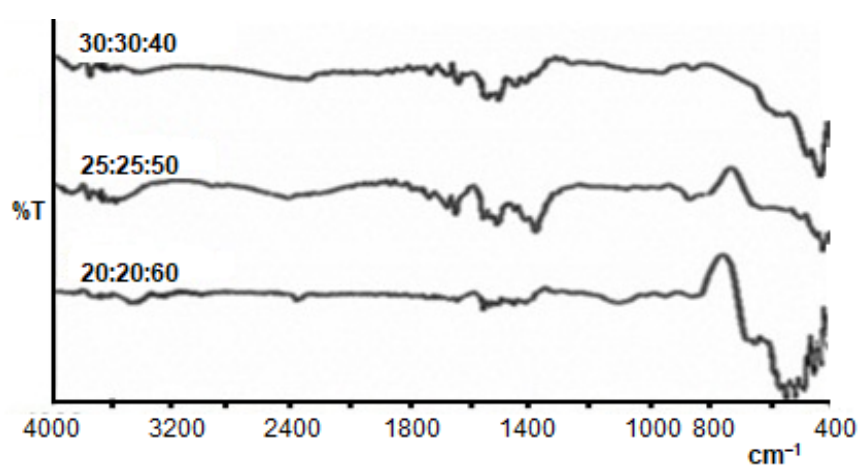

Fig 2. Infrared spectra of different ratios of $\mathrm{NiO}-\mathrm{CoO}-$ $\mathrm{MgO}$

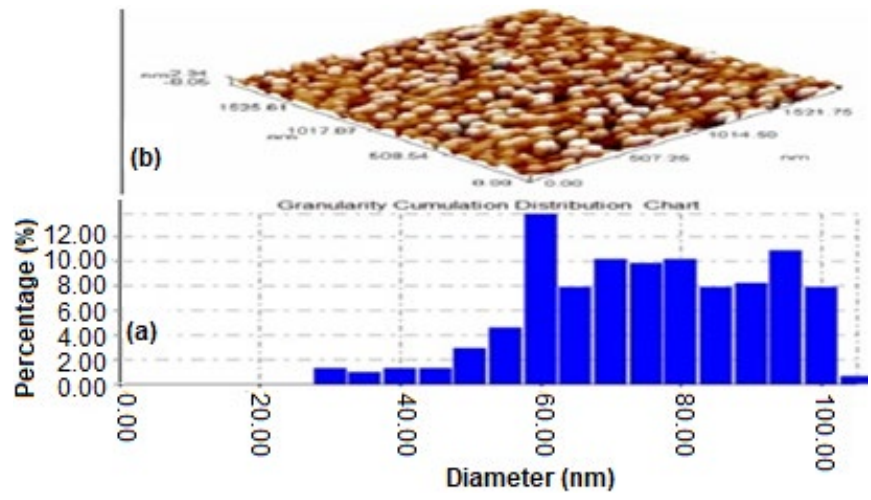

Fig 4. Atomic force microscopy for $25 \mathrm{NiO}-25 \mathrm{CoO}-$ $50 \mathrm{MgO}$ catalyst: (a) particle size distribution histogram, (b) Image of surface 


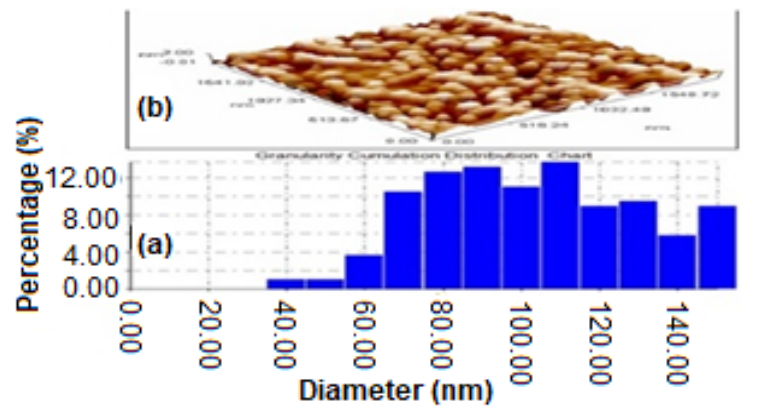

Fig 5. Atomic force microscopy for 30NiO-30CoO$40 \mathrm{MgO}$ catalyst: (a) particle size distribution histogram, (b) image of surface

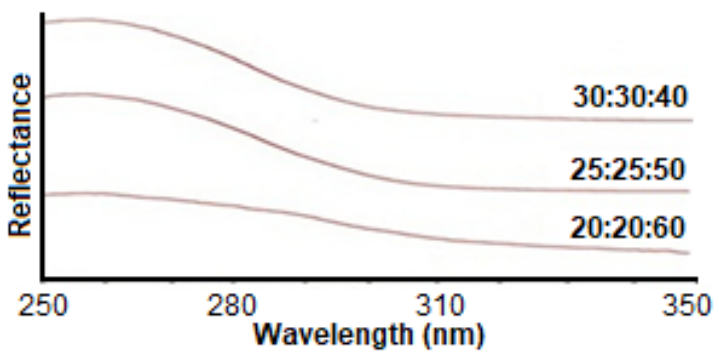

Fig 6. Band gap energies for the ratios of the prepared catalyst

second ratio 25:25:50, this may be due to the decreasing of particle size of catalyst and best distribution of mixed oxides of the catalyst.

\section{The Activity of Dye Decolorization over the Prepared Co-catalyst}

\section{Choose the best ratio of the prepared catalyst}

The best ratio of $\mathrm{NiO}-\mathrm{CoO}-\mathrm{MgO}$, that which gave the high decolorization efficiency of Celestin blue $\mathrm{B}$, was 25:25:50 as shown in Table 3 and Fig. 7, this may be due to the best distribution of active sites on the catalyst surface in this ratio of mixed oxides.

\section{Decolorization efficiency of CBB Dye over different weights of catalyst}

Effect of the doses of the catalyst on the decolorization efficiency of CBB dye are shown in Table 4 and Fig. 8, which show the increasing catalytic activity of dye decolorization by increasing the amount of catalyst from 0.02 to $0.08 \mathrm{~g}$. Possibly, this is due to the increasing of active sites number on the surface of catalyst and then increasing the decolorization of dye. Increasing the catalyst

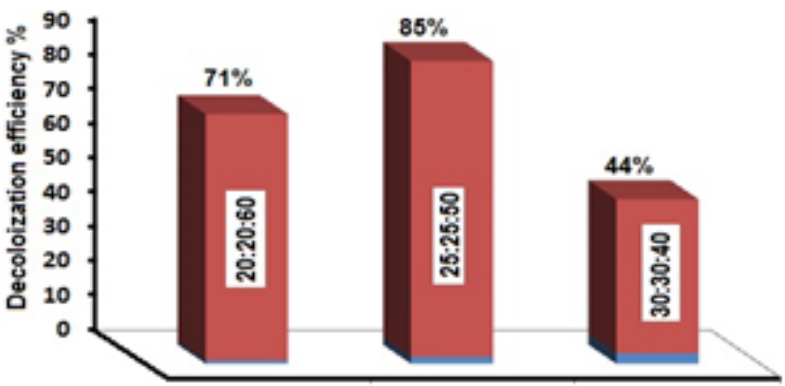

Fig 7. Decolorization efficiency of Celestine blue B dye over $0.2 \mathrm{~g}$ of different ratios of $\mathrm{CoO}-\mathrm{NiO}-\mathrm{MgO}$ catalyst after $60 \mathrm{~min}$

Table 3. Decolorization efficiency of Celestine blue B dye over $0.2 \mathrm{~g}$ of different ratios of $\mathrm{CoO}-\mathrm{NiO}-\mathrm{MgO}$ catalyst

\begin{tabular}{cc}
\hline $\begin{array}{c}\text { Ratio of CoO-NiO-MgO } \\
\text { Catalyst }\end{array}$ & $\begin{array}{c}\text { Decolorization Efficiency } \\
\%\end{array}$ \\
\hline 20CoO:20NiO:60MgO & 71.12 \\
25CoO:25NiO:50MgO & 85.46 \\
30CoO:30NiO:40MgO & 44.54 \\
\hline
\end{tabular}

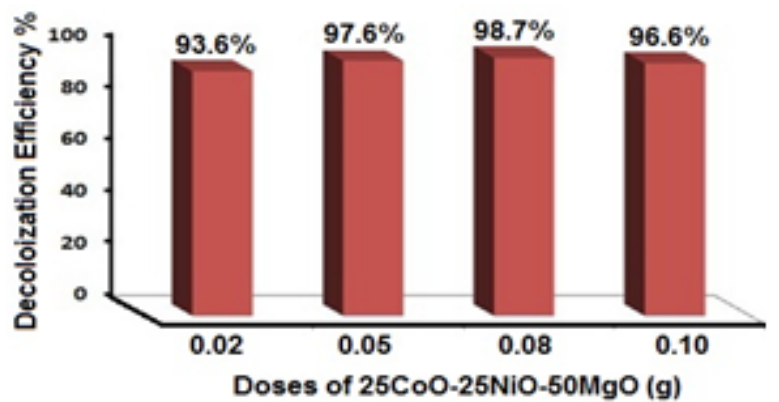

Fig 8. Decolorization efficiency of $\mathrm{CBB}$ dye over the different weight of $25 \mathrm{CoO}-25 \mathrm{NiO}-50 \mathrm{MgO}$ composite catalyst after $60 \mathrm{~min}$

Table 4. Decolorization efficiency of Celestine blue B dye over different weights of $25 \mathrm{CoO}-25 \mathrm{NiO}-50 \mathrm{MgO}$ catalyst

\begin{tabular}{cc}
\hline $\begin{array}{c}\text { Weight of Catalyst } \\
(\mathrm{g})\end{array}$ & $\begin{array}{c}\text { Decolorization } \\
\text { Efficiency } \%\end{array}$ \\
\hline 0.02 & 93.6 \\
0.05 & 97.6 \\
0.08 & 99.7 \\
0.10 & 96.6 \\
\hline
\end{tabular}




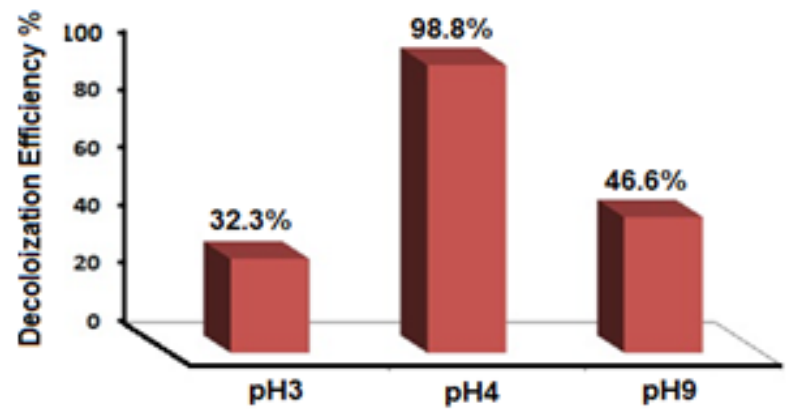

Fig 9. Decolorization efficiency of $\mathrm{CBB}$ dye at different $\mathrm{pH}$ over $25 \mathrm{CoO}-25 \mathrm{NiO}-50 \mathrm{MgO}$ composite catalyst

amount to $0.1 \mathrm{~g}$ leads to decrease the decolorization efficiency of dye because of the decreasing of active sites number of the catalyst surface [18-20] by the agglomeration of catalyst particles (increasing the turbidity). This can lead to light scattering and prevent it from transmitted to the inner reaction mixture which leads to a decrease in the efficiency of CBB dye over the used catalyst [21].

\section{Decolorization efficiency of CBB dye at different pHs values over the ternary catalyst}

One of the important factors that can be affected by the catalytic decolorization efficiency of $\mathrm{CBB}$ dye over $\mathrm{NiO}-\mathrm{CoO}-\mathrm{MgO}$ is the $\mathrm{pH}$ of the reaction mixture, which is affected by the rate of catalytic reaction. The optimum efficiency of dye decolorization which was around $84.6 \%$ at $\mathrm{pH}=4$, at $298 \mathrm{~K}$, and a catalyst dosage equal to $0.08 \mathrm{~g}$. On the other hand, in basic media at $\mathrm{pH}=9$, the decolorization efficiency of $\mathrm{CBB}$ dye was decreased as shown in Fig. 9.

From these results it can be seen that, the decolorization efficiency of CBB dye increased in acidic media because of the attraction force between the anionic groups of dye and decreased in basic media because of the repulsion force between the anionic groups of the dye with negative charge of the catalyst surface reached to $46.4 \%$ at $\mathrm{pH}=9$ [22-24]. The increasing of $\mathrm{pH}$ values cause a decrease of catalytic activity of the prepared catalyst because of the increasing rate of recombination between $\left(\mathrm{e}^{-} / \mathrm{h}^{+}\right)$pairs of the reaction mixture [25-26]. On the other hand, there was an increase in the efficiency of dye decolorization at acidic $\mathrm{pH}$ values and this effect can

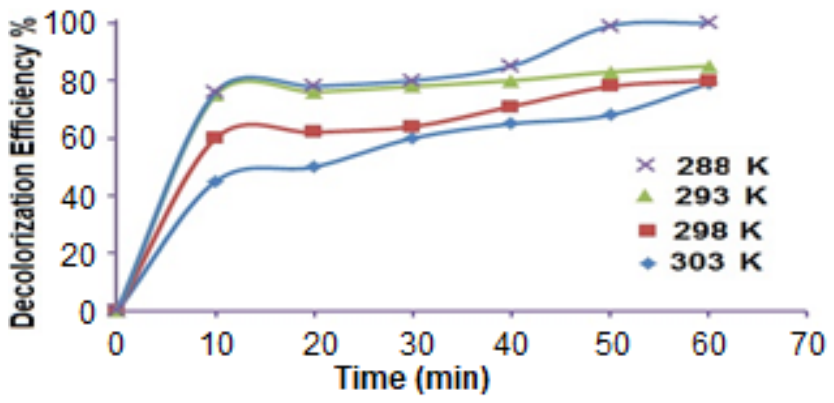

Fig 10. Decolorization efficiency of Celestine blue B dye over $25 \mathrm{CoO}-25 \mathrm{NiO}-50 \mathrm{MgO}$ at different temperature

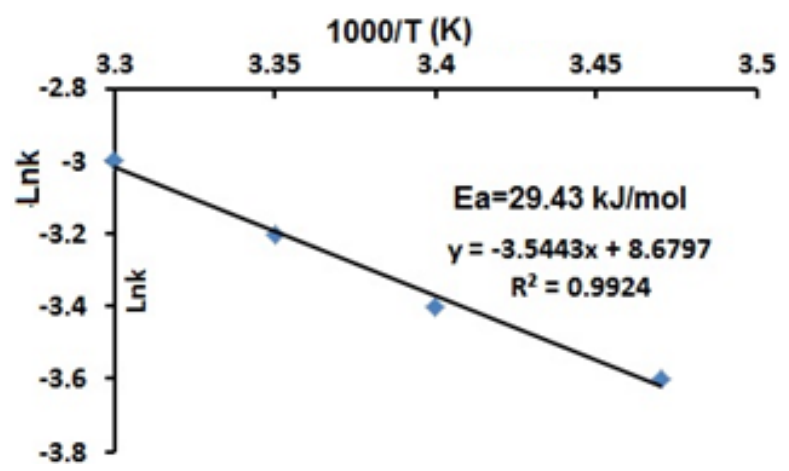

Fig 11. The activation energy for photocatalytic decolorization of Celestine blue $\mathrm{B}$ dye over $25 \mathrm{CoO}$ $25 \mathrm{NiO}-50 \mathrm{MgO}$ nano-composite catalyst

be related to increasing the attraction between dye molecules and the positively charged surface.

\section{Decolorization of CBB dye over the prepared catalyst at different temperatures}

The decolorization efficiency of CBB dye was carried out at different temperature 288, 293, 298 and $303 \mathrm{~K}$ by using the best weight $0.08 \mathrm{~g}$ of $25 \mathrm{CoO}-25 \mathrm{NiO}-$ $50 \mathrm{MgO}$ catalyst at $\mathrm{pH}=4$, as shown in Fig. 10 , to show the effect of temperature on the decolorization efficiency of the dye.

From the results that are shown in Fig. 10, it was found that the decolorization efficiency of dye was increased with the increase of reaction temperatures to $303 \mathrm{~K}$ and increase with the development of reaction time up to $1 \mathrm{~h}$ to reach $99.9 \%$, this observation can be attributed to the increase in the production of free radicals at higher temperatures [27-28].

The activation energy for the photocatalytic decolorization of Celestine blue b equal to $29.4 \mathrm{~kJ} \mathrm{~mol}^{-1}$, 
Table 5. Thermodynamic data for photocatalytic decolorization of Celestine blue $\mathrm{B}$ dye over $0.08 \mathrm{~g}$ of $25 \mathrm{CoO}-25 \mathrm{NiO}-50 \mathrm{MgO}$ in $\mathrm{pH}=4$ and different temperature

\begin{tabular}{|c|c|c|c|c|}
\hline Temp. (K) & 288 & 293 & 298 & 303 \\
\hline Ln $k$ & -3.6 & -3.4 & -3.2 & -3.0 \\
\hline $\begin{array}{c}\Delta G \\
\left(\mathrm{~kJ} \cdot \mathrm{mol}^{-1}\right)\end{array}$ & -18347.3 & -18607.8 & -18689.9 & -19295.43 \\
\hline $\begin{array}{c}\Delta \mathrm{H} \\
\left(\mathrm{kJ} \cdot \mathrm{mol}^{-1}\right)\end{array}$ & 27.0055 & 26.963 & 26.900 & 29.88 \\
\hline $\begin{array}{c}\Delta S \\
\left(\mathrm{~J} \cdot \mathrm{mol}^{-1}\right)\end{array}$ & 63.8 & 63.64 & 63.88 & 63.77 \\
\hline
\end{tabular}

that was calculated from Fig. 11. The low activation energy due to the transport of photoelectrons through the catalyst to the adsorbed oxygen on the surface [29].

From the effect of temperature on the rate of reaction, thermodynamic parameters in Table 5 can be calculated for the photocatalytic decolorization of $\mathrm{CBB}$ dye over the optimum mass of the best ratio of the prepared catalyst by applying the following equations:

$\Delta \mathrm{H}=\mathrm{Ea}-\mathrm{RT}$

$\ln \mathrm{k}=\Delta \mathrm{S} / \mathrm{R}-\Delta \mathrm{H} / \mathrm{RT}$

$\Delta \mathrm{G}=\Delta \mathrm{H}-\mathrm{T} \Delta \mathrm{S}$

whereas $\mathrm{Ea}$ is the activation energy of catalytic decolorization of dye, $\Delta \mathrm{S}$ is the change in entropy, $\Delta \mathrm{H}$ is a change in enthalpy, $\mathrm{k}$ is a rate constant for the reaction, $\mathrm{T}$ is the absolute temperature of reaction, $\Delta \mathrm{G}$ is the change in free energy.

From the results in Table 5, it can be seen that enthalpy of reaction $(\Delta \mathrm{H})$ have positive values, showing that the process of decolorization of dye was an endothermic reaction. Besides that, the results also exhibited relatively low positive values of entropy $(\Delta S)$. These positive values of entropy would facilitate reaction processing. The overall value of Gibbs free energy $(\Delta G)$ for reaction showed negative values, which confirms that photodecolorization process of $\mathrm{CBB}$ dye over the used catalyst was a spontaneous process. [30-31].

\section{- CONCLUSION}

The ternary catalyst $\mathrm{NiO}-\mathrm{CoO}-\mathrm{MgO}$ was obtained by co-precipitation method in the ratios of the component oxides 20:20:60, 25:25:50, and 30:30:40, respectively at $600{ }^{\circ} \mathrm{C}$ for $4 \mathrm{~h}$, and these were followed by characterization by PXRD, FTIR and AFM spectroscopies. The catalytic activity of $\mathrm{NiO}-\mathrm{CoO}-\mathrm{MgO}$ catalyst was tested in depolarization of Celestine blue $\mathrm{B}$ dye, which given a high depolarization efficiency in the ratio 25:25:50. The high catalytic activity of the prepared catalyst was at the optimal conditions: catalyst dosage $=$ $0.08 \mathrm{~g} / \mathrm{L}, \mathrm{pH}=4$, temperature $=25^{\circ} \mathrm{C}$, and for a period of $60 \mathrm{~min}$., these optimal conditions give a decolorization efficiency of dye reached to $99.9 \%$.

\section{- ACKNOWLEDGMENTS}

We would like to thank the University of Babylon, Faculty of Science to provide all the requirements to complete this research and for funding this work. Also, the authors thank, all researcher for their cooperation and help to complete this work.

\section{- REFERENCES}

[1] Hutchings, G.J., 2009, Heterogeneous catalystdiscovery and design, J. Mater. Chem., 19 (9), 12221235.

[2] Xie, Z., Liu, Z., Wang, Y., Yang, Q., Xu, L., and Ding, W., 2010, An overview of recent development in composite catalyst from porous materials for various reactions and processes, Int. J. Mol. Sci., 11 (5), 2152-2187.

[3] Sevcik, P., Cik, G., Vlna, T., and Mackulak, T, 2009, Preparation and properties of a new composite photocatalyst based on nanosized titanium dioxide, Chem. Pap., 63 (2), 249-254.

[4] Fatma, F., Hariani, P.L., Riyanti, F., and Sepriani, W., 2017, Desorption and re-adsorption of procion red MX-5B dye on alumina-activated carbon composite, Indones. J. Chem., 18 (2), 222-228.

[5] Ahmed, L.M., Saaed, S.I., and Marhoon, A.A., 2018, Effect of oxidation agents on photo-decolorization of vitamin $\mathrm{B} 12$ in the presence of $\mathrm{ZnO} / \mathrm{UV}-\mathrm{A}$ system, Indones. J. Chem., 18 (2), 272-278.

[6] Petitto, S.C., Marsh, E.M., Carson, G.A., and Langell, M.A., 2008, Cobalt oxide surface chemistry: The interaction of $\mathrm{CoO}\left(\begin{array}{lll}1 & 0 & 0\end{array}\right), \mathrm{Co}_{2} \mathrm{O}_{3}(1$ 
$10)$ and $\mathrm{Co}_{3} \mathrm{O}_{4}\left(\begin{array}{lll}1 & 1 & 1\end{array}\right)$ with oxygen and water, J. Mol. Catal. A: Chem., 281 (1-2), 49-58.

[7] Mathew, J., and Shetty, N., 2017, Treatment of wastewater using synthesized photocatalyst cobalt oxide $\mathrm{CO}_{3} \mathrm{O}_{4}$, Int. J. Civil Eng. Technol., 8 (4), 18401844.

[8] Helmes, C.T., Sigman, C.C., Fung, V.A., Thompson, K., Doeltz, M.K., Mackie, M., Klein, T.E., and Lent, D., 1984, A study of azo and nitro dyes for the selection of candidates for carcinogen bioassay, $J$. Environ. Sci. Health, Part A, 19 (2), 97-231.

[9] Julkapli, N.M., and Bagheri, S., 2015, Magnesium oxide as a heterogeneous catalyst support, Rev. Inorg. Chem., 36 (1), 1-41.

[10] Roxon, J.J., Ryan, A.J., and Wright, S.E., 1967, Reduction of water-soluble azo dyes by intestinal bacteria, Food Cosmet. Toxicol., 5 (3), 367-369.

[11] Corro, G., Fierro, J.L.G., and Odilón Vázquez, C., 2005, Strong improvement on $\mathrm{CH}_{4}$ oxidation over $\mathrm{Pt} / \gamma-\mathrm{Al}_{2} \mathrm{O}_{3}$ catalysts, Catal. Commun., 6 (4), 287-292.

[12] Nazarkovsky, M.A., Gun'ko, V.M., Wójcik, G., Czech, B., Sobieszek, A., Skubiszewska-Zięba, J., Janusz, W., and Skwarek, E., 2014, Band-gap change and photocatalytic activity of silica/titania composite associated with incorporation of $\mathrm{CuO}$ and $\mathrm{NiO}$, Chem. Phys. Technol. Surf., 5 (4), 421-437.

[13] Vázquez-Cuchillo, O., Cruz-López, A., BautistaCarrillo, L.M, Bautista-Hernández, A., Martínez, L.M.T., and Lee, S.W., 2010, Synthesis of $\mathrm{TiO}_{2}$ using different hydrolysis catalysts and doped with $\mathrm{Zn}$ for efficient degradation of aqueous phase pollutants under UV light, Res. Chem. Intermed., 36 (1), 103113.

[14] Song, Y.L., Li, J.T., and Bai, B., 2010, $\mathrm{TiO}_{2}$-assisted photodegradation of direct blue 78 in aqueous solution in sunlight, Water Air Soil. Pollut., 213 (14), 311-317.

[15] Halbus, A.F., Lafta, A.J., Athab, Z.H., and Hussein, F.H., 2014, Adsorption of reactive yellow dye 145 from wastewater onto Iraqi Zahdy and Khestawy date palm seeds activated carbons, Asian J. Chem., 26, S167-S172.
[16] Wanke, S.E., and Flynn, P.C., 1975, The sintering of supported metal catalysts, Catal. Rev. Sci. Eng., 12 (1), 93-135.

[17] Attia, A.J, Kahdim, S.H., and Hussein, F.H., 2008, Photocatalytic degradation of textile dyeing wastewater using titanium dioxide and zinc oxide, E-J. Chem., 5 (2), 219-223.

[18] Mora, M., López, M.I., Jiménez-Sanchidrián, C., and Ruiz, J.R., 2010, Ca/Al mixed oxides as catalysts for the Meerwein-Ponndorf-Verley reaction, Catal. Lett., 136 (3-4), 192-198.

[19] Mohammad, E.J., Kathim, S.H., and Attia, A.J., 2015, Removal of reactive yellow 145 dye from simulated industrial waste waters over prepared supported (Co, Ni) ${ }_{3} \mathrm{O}_{4} / \mathrm{Al}_{2} \mathrm{O}_{3}$ spinel catalyst, Res. J. Pharm. Biol. Chem. Sci., 6 (4), 717-726.

[20] Yuliati, L., Roslan, N.A., Siah, W.R., and Lintang, H.O., 2017, Cobalt oxide-modified titanium dioxide nanoparticle photocatalyst for degradation of 2,4-dichlorophenoxyacetic acid, Indones. J. Chem., 17 (2), 284-290.

[21] Ge, X., Liu, Y., Goh, F.W.T., Hor, T.S.A., Zong, Y., Xiao, P., Zhang, Z., Lim, S.H., Li, B., Wang, X., and Liu, Z., 2014, Dual-phase spinel $\mathrm{MnCo}_{2} \mathrm{O}_{4}$ and spinel $\mathrm{MnCo}_{2} \mathrm{O}_{4} /$ nanocarbon hybrids for electrocatalytic oxygen reduction and evolution, ACS Appl. Mater. Interfaces, 6 (15), 12684-12691.

[22] Sharifi, S.L., Shakur, H.R., Mirzaei, A., Salmani, A., and Hosseini, M.H., 2013, Characterization of cobalt oxide $\mathrm{Co}_{3} \mathrm{O}_{4}$ nanoparticles prepared by various methods: effect of calcination temperatures on size, dimension and catalytic decomposition of hydrogen peroxide, Int. J. Nanosci. Nanotechnol., 9 (1), 51-58.

[23] Selvam, N.C.S., Kumar, R.T., Kennedy, L.J., and Vijaya, J.J., 2011, Comparative study of microwave and conventional methods for the preparation and optical properties of novel $\mathrm{MgO}-m i c r o$ and nanostructures, J. Alloys Compd., 509 (41), 9809-9815.

[24] Purnawan, C., Wahyuningsih, S., and Kusuma, P.P., 2016, Photocatalytic and photoelectrocatalytic degradation of methyl orange using graphite $/ \mathrm{PbTiO}_{3}$ composite, Indones. J. Chem., 16 (3), 347-352. 
[25] Galván-Ruiz, M., Hernández, J., Baños, L., NoriegaMontes, J., and Rodríguez-García, M.E., 2009, Characterization of calcium carbonate, calcium oxide, and calcium hydroxide as starting point to the improvement of lime for their use in construction, $J$. Mater. Civ. Eng., 21 (11), 694-698.

[26] Singh, J., Hudson, M.S.L., Pandey, S.K., Tiwari, R.S., and Srivastava, O.N., 2012, Structural and hydrogenation studies of $\mathrm{ZnO}$ and $\mathrm{Mg}$ doped $\mathrm{ZnO}$ nanowires, Int. J. Hydrogen Energy, 37 (4), 37483754.

[27] Ni, Y., Ge, X., Zhang, Z., Liu, H., Zhu, Z., and Ye, Q., 2001, A simple reduction-oxidation route to prepare $\mathrm{Co}_{3} \mathrm{O}_{4}$ nanocrystals, Mater. Res. Bull., 36 (13-14), 2383-2387.
[28] Wilson, S.J., 1979, The dehydration of boehmite, $\gamma$ $\mathrm{AlOOH}$, to $\gamma-\mathrm{Al}_{2} \mathrm{O}_{3}$, J. Solid State Chem., 30 (2), 247-255.

[29] Gassim, F.A.Z.G., Alkhateeb, A.N., and, Hussein, F.H., 2007, Photocatalytic oxidation of benzyl alcohol using pure and sensitized anatase, Desalination, 209 (1-3), 342-349.

[30] Ahmed, L.M., and Hussein, F.H., 2014, Roles of Photocatalytic Reactions of Platinized $\mathrm{TiO}_{2}$ Nanoparticles, LAP Lambert Academia Published, Germany.

[31] Zuafuani, S.I., and Ahmed, L.M., 2015, Photocatalytic decolourization of direct orange dye by zinc oxide under UV irradiation, Int. J. Chem. Sci., 13 (1), 187-196. 